Haya: The Saudi Journal of Life Sciences

Abbreviated Key Title: Haya Saudi J Life Sci ISSN 2415-623X (Print) |ISSN 2415-6221 (Online) Scholars Middle East Publishers, Dubai, United Arab Emirates Journal homepage: http://scholarsmepub.com/haya/

Original Research Article

\title{
A Report on Multiple Births in Hanuman Langur (Semnopithecus Entellus) in and Around Jodhpur, Rajasthan
}

\author{
Goutam Sharma
}

Animal Behaviour Unit, Department of Zoology, J.N.V. University, Jodhpur Rajasthan India

DOI: $10.36348 /$ SJLS.2019.v04i10.004 $\quad$ | Received: 19.11.2019| Accepted: 26.11.2019| Published: 28.11 .2019

*Corresponding author: Goutam Sharma

\section{Abstract}

The present study covers multiple on Hanuman langurs, Semnopithecus entellus, and species living around Jodhpur, India. The current statement delivers report multiple births during 2018-2019. Four cases of multiple births (three twins and one triplet birth) were observed during study in species at Jodhpur. The adult female with twins/triplet birth expended more time in foraging and resting. The research suggested that adult females with multiple deliveries can successfully survive in a study environment.

Keywords: Multiple, Births, Semnopithecus entellus, Jodhpur, Rajasthan.

Copyright @ 2019: This is an open-access article distributed under the terms of the Creative Commons Attribution license which permits unrestricted use, distribution, and reproduction in any medium for non-commercial use (NonCommercial, or CC-BY-NC) provided the original author and source are credited.

\section{INTRODUCTION}

Maximum primate and non-human primate species give birth to a single progeny [1], but Twins births happen with variable frequency in species [2-4]. Old World monkeys and apes are measured to be single births are the rule [4-6], but multiple (twins/triplet) births do rarely occur. Among the Hanuman langurs of Jodhpur, some twins [7-9] births were observed. But, the frequency of its occurrence is still unknown. It was reported that multiple births might happen in many species. Abel [10] one of the initial challenges at quantifying the frequency of multiple births in these primates.

Multiple births frequently happen only in Callitrichids [11, 12] and some species of Strepsirhines [13-15]. Although twinning does arise among most anthropoid primates, the frequency of twins' births is shallow [15-17]. Very few observations on the behavioral expansion of twins under free-ranging conditions are available [18-21]. Hrdy [7] briefly stated three cases of twins in langur's species that survived between 4 and 24 months. Winkler [8] and [9] observed twinning and described the development of twins and in Hanuman langurs at Jodhpur.

Hartman [22] subsequently doubted if the mother should not possibly be credited at least with twins (though not with triplets). Only one case of a triple birth in Old-World monkey has been reliably noted: in 1945, a black Celebes macaque gave birth to triplets. All newborns were stillborn, and the mother died from exhaustion [23].

\section{MATERIALS AND METHODS}

Jodhpur is situated in Rajasthan at the eastern edge of the Great Indian Desert, lives a geographically isolated population of about 2500 langurs comprising 39 one-male bisexual troops and 17 bachelor's groups. The langurs' species feed on about 190 wild and cultivated plant species [24-29. For holy reasons, local people offer most of the groups with vegetables, fruits, and cooked food. In some groups, the provisioning accounts very high. The animals are easy to study since they spend most of their time on the ground. The reproductive units are bisexual troops with one or two adult alpha male. As a rule, in species, males never carry or feed infants [9]. Explanations have done by focal animal and ad libitum sampling. During focal animal sampling in study troops sessions (30 min. each), behavior and spatial associations of the twins and their mothers were noted. In the subsequent investigation only, those selections are measured in which twins and triplet infants could be observed simultaneously. Facts are presented as a percent of total focal animal reflection time.

\section{RESULTS AND DISCUSSION}

A 45-year-long study has been supported on Hanuman langurs, Semnopithecus entellus, species living around Jodhpur, India. The present statement delivers report multiple births during 2018-2019. Four 
cases of multiple births (three twins and one triplet birth) were observed during study in species at Jodhpur.

In langur species where there is almost no paternal care of infants but allomothering is very usual in twinning is some expensive for the mother who has to meet the supplementary energetic demands of raising two offspring at once. Data we have presented suggest that twinning influenced the twins' physical development and the twinning mother's ecological strategies. Her elevated energy costs of rearing two offspring have not compensated with increased energy uptake.

Table-1: Twins and Triplet births in the langur population around Jodhpur 2018-2019

\begin{tabular}{|c|c|c|c|c|c|c|c|c|}
\hline S. No & $\begin{array}{l}\text { Troop } \\
\text { No. }\end{array}$ & Location & $\begin{array}{l}\text { Observation } \\
\text { Month }\end{array}$ & Birth & $\begin{array}{l}\text { Estimated } \\
\text { age }\end{array}$ & $\begin{array}{l}\text { Sex of } \\
\text { Infants }\end{array}$ & $\begin{array}{l}\text { Behaviour } \\
\text { Similarity }\end{array}$ & $\begin{array}{l}\text { Survival } \\
\text { (as on Sept. 2019) }\end{array}$ \\
\hline 1 & B-4 & Nimba & Jan-2018 & Twins & 11 days & $\hat{\sigma}-\hat{0}$ & $70 \%$ & Alive \\
\hline 2 & B-7a & Mandore & May-2018 & Twins & 10 days & 으-우 & $65 \%$ & Alive \\
\hline 3 & B-7 & $\begin{array}{l}\text { Mandore } \\
\text { Fort }\end{array}$ & Feb- 2019 & Twins & 2 days & $\hat{0}-\sigma^{1}$ & $73 \%$ & Alive \\
\hline 4 & B-7 & $\begin{array}{l}\text { Mandore } \\
\text { Fort }\end{array}$ & March-2019 & Triplet & 4 days & $\begin{array}{l}\text { Q- }+ \text { - } \\
\text { o. }\end{array}$ & $60 \%$ & Alive \\
\hline
\end{tabular}

During the study, multiple births recorded the proportion of time in which the twins were in contact with their mother and compared it to that of a singleton female offspring. These results have shown that increased costs on the twin's mother and slower rates of physical and social development of the twins compared to singletons have had direct implications on the subsequent reproductive output of their mothers [30, 20,
$3,32,33]$. The response of the twins was mostly the same. In more than $60-70 \%$ of all activity sessions, both twins presented the same tone, with "nipple connection" and "movement" predominant. But in case of triplet birth, it was very tough for the third baby to make suckling in suitable means. Variances in physical strength and growth were apparent within pairs.

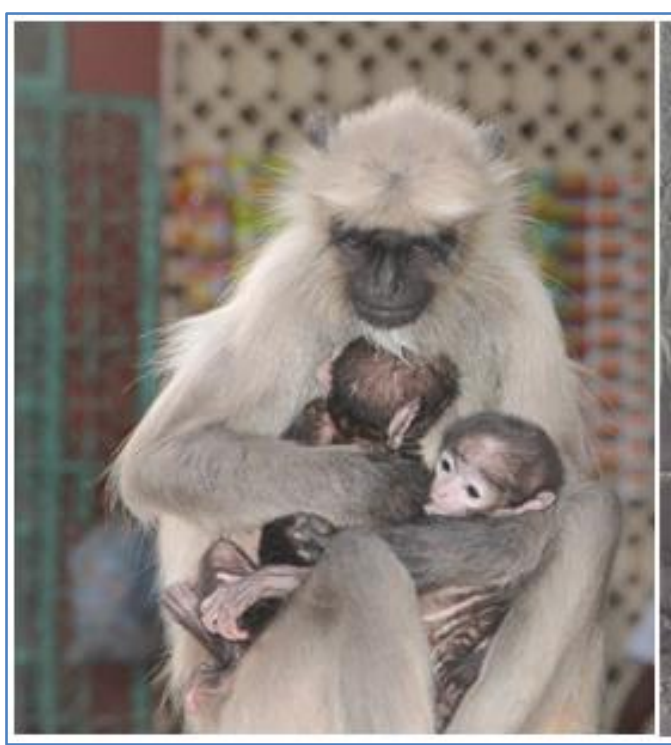

In the Nimba (B-4) troop, one set of twins was found another one set of twin's births found in Mandore (B-7a) and one twin, and a triplet birth was found in the Mandore Fort (B-7) troop during the study period. All sets were observed as often as routine fieldwork allowed. The Mandore troops live in a garden about 8$10 \mathrm{~km}$ north of the city of Jodhpur (see in table 1).

Non-human Primates that have consistent multiple births have improved strategies to deal with the increased costs of twinning by evolving or retaining behaviors. That reduces the maternal cost of caring for numerous offspring (paternal care and carrying 'helpers'

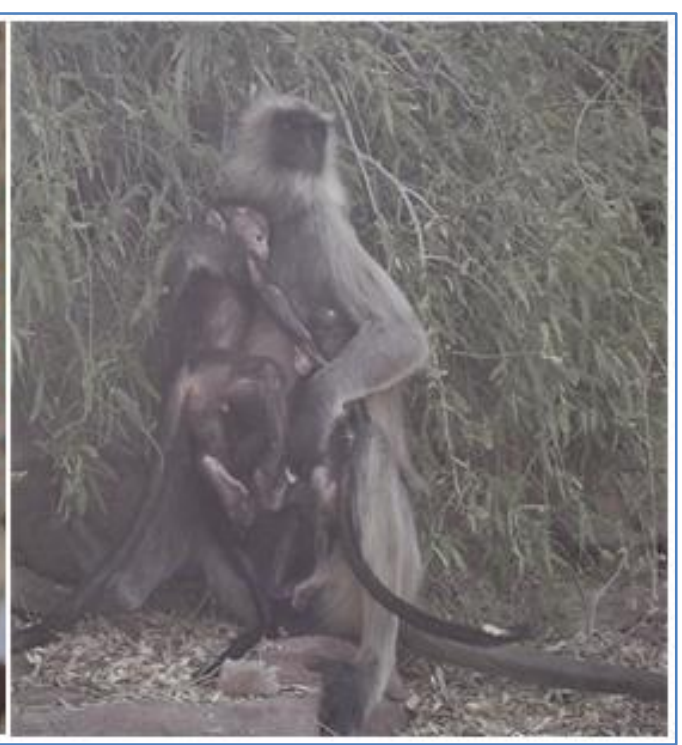

in the Callitrichidae or the space of family in temporal nests in some Strepsirhines [34]. For the study degree of behavioral pattern, the behavior of each pair of twins was studied according to the sampling method: The twins' action at the beginning of a focal animal sample labeled the start of the first activity bout. It finished when at least one of the twins stopped its activity and started another, marking the beginning of the second bout, etc.

Differences within each pair are shallow compared to differences between couples. All infants visibly established a partiality for one nipple. In the 
triplet birth, it has observed that the infant got not as much of nipple contact comparatively other two infants.

Nakamichi's [30] study on Japanese monkeys and Chapman and Chapman [18] on howling monkeys, langur twins spent a maximum of their time close to each other. Behavior patterns were mostly harmonized which facts towards a parallel set of practices for each twin in the course of its growth [9]. The almost limited use of a preferred nipple starts around the fifth and six weeks of life when physical variances between the twins have become apparent. Hrdy [7], Sharma, et al. [9], and Swami [35] speculated that suckling might be the critical factor in twin survivorship. In the current study, females could well succeed to nurse two infants at a time. But sometimes a sporadic triplet birth is difficult for the mother.

We documented qualitative data on the growth and social interactions of the twins and triplet birth. Females that had twins or triplets had the highest amount of resting, feeding time, and spend the low amount in moving. Mother had the most moderate average daily travel distance and relied more heavily on flowers, leaves, and provisioning.

The female that delivery to the twins in focal groups had studied during their first five to six months and her activity budget were compared to assess her behavioral changes. Our statement displays that female langur with multiple births can positively survive. The adult female with twins/triplet birth expended more time in foraging and resting. A study suggested that adult females with many deliveries can successfully be surviving in a wild environment. For that, adult females adapted some changes in behavior patterns to adjust the heavy burden. There is a lot of provisioning in study troops. So that adult female gets food without an extra struggle. Mother's behavioral strategies also facilitated the survivorship of twins. Provisioning by resident people to free-living langur groups usually leads to a significant increase in newly available resources for the langur population. The similar behaviors that have considered in the present analysis include foraging, allomothering, short-distance movement, affiliation, contact, retreat, and feeding supplant.

Sinha et al. [36] also suggested that the social organization of bonnet macaque (Macaca radiata) is affected by traveling provisioning. Somewhat disturbingly, scientific reports after the 1980s tended to avoid descriptions of artificially acquired food despite its effect on the behavior and ecology of wild nonhuman primates having become clear [37, 38]. The twins spent much time in contact with and proximity to each other, and as their interactions were peaceful, no dominance relations between them were assumed. Each twin interacted with other infants and juveniles less frequently than did the single infants. Sugiyama et al. [39] study nine samples of twins and concluded that the improved amount of this phenomenon has connected to the high nutritional condition of the mother. Hsu et al. [40], who also found a high occurrence of twinning among Formosan macaques (Macaca cyclopis) [41, 42].

Geissmann [17] documented twins in hamadryas baboons (Papio hamadryas). Hsu et al. [38] reported twins habituated (wild but provisioned by tourists) Formosan macaque (Macaca cyclopis) groups as an exceptionally high frequency. Twinning is relatively rare in wild populations of anthropoid primates. Some reports on captive populations look to indicate a lower survival of twins compared to singletons [16, 30, 4, 21, 20, 38, 43, 33, 32]. Studies of howler monkeys (Alouatta palliata) [18, 44] and muriquis (Brachyteles hypoxanthus) [45] have reported twinning in wild populations.

It has continuously suggested that twinning frequency in langur species very low the same as in other non-human primates. Studying twins' birth is a well-known method for disentangling the influences of the environment and genes on our biology and behavior. Because identical twins share their entire genome and non-identical twins on average share only half of the genetic variation. Twin/ triplet birth studies offer valuable tools for genetic and epigenetic research.

\section{ACKNOWLEDGMENT}

Authors are grateful to Prof. L.S. Rajpurohit, Head, Department of Zoology, J.N.V. University, Jodhpur for the logistic support. Thanks are due to Dr. Devilal, Dr. Aazad Ojha, and Arjun Singh for their help in the field.

\section{REFERENCES}

1. Leutenegger, W. (1979). Evolution of litter size in primates. The American Naturalist, 114(4), 525531.

2. Wildt, D. E., \& Dukelow, W. R. (1974). The nonhuman primate as a model for human twinning. Laboratory Primate Newsletter, 13(4), 15-18.

3. Ely, J. J., Frels, W. I., Howell, S., Izard, M. K., Keeling, M. E., \& Lee, D. R. (2006). Twinning and heteropaternity in chimpanzees (Pan troglodytes). American Journal of Physical Anthropology: The Official Publication of the American Association of Physical Anthropologists, 130(1), 96-102.

4. Harms, J. W. (1956). Fortpflanzungsbiologie. In (H. Hofer, AH Schultz and D. Starck, eds.). Primatologia. Handbuch der Primatenkunde, Vol. I: Systematik, Phylogenie, Ontogenie.

5. Hendricky, A.G., \& Nelson, G., (1971). Reproductive failure. In (E.S.E. Hafez, ed.) Comparative reproduction of nonhuman primates, 403-425. Springfield, Ill.: Thomas. 
6. Yerkes, R.M. (1934). Multiple births in anthropoid apes. Science; 79: 430-431.

7. Hrdy, S. B. (1976). Care and exploitation of nonhuman primate infants by conspecifics other than the mother. In Advances in the Study of Behavior (Vol. 6, pp. 101-158). Academic Press.

8. Winkler, P., Wrogemann, D., \& Prestel, H. (1989). Twins in free-ranging Hanuman langurs (Presbytis entellus). Primates, 30(2), 255-259.

9. Sharma, G. (2007). Paternal care in Hanuman langur, Semnopithecus entellus entellus, around Jodhpur (India) (Doctoral dissertation, $\mathrm{PhD}$ thesis, Jai Narain Vyas University, Jodhpur).

10. Abel, W. (1933). Zwillinge bei Mantelpavianen und die Zwillingsanlage innerhalb der Primaten. Zeitschrift für Morphologie und Anthropologie, (H. 2), 266-275.

11. Ah-King, M., \& Tullberg, B. S. (2000). Phylogenetic analysis of twinning in Callitrichinae. American Journal of Primatology: Official Journal of the American Society of Primatologists, 51(2), 135-146.

12. Wilson Goldizen, A. (1987). Tamarins and Marmosets: comunal care of offsping. Primate Societies, 34-43.

13. Parga, J. A., \& Nansen, S. C. (2019). Heteropaternity of twins in ring-tailed lemurs (Lemur catta). American Journal of Physical Anthropology, 169(2), 270-278.

14. Xia, D., Li, J., Matheson, M. D., Sun, L., Sun, B., \& Zhu, Y. (2012). First occurrence of twins in provisioned free-ranging Tibetan macaques (Macaca thibetana) at Huangshan, China. Primates, 53(1), 1-5.

15. Chapman, C. A., Walker, S., \& Lefebvre, L. (1990). Reproductive strategies of primates: the influence of body size and diet on litter size. Primates, 31(1), 1-13.

16. Leighty, K. A., Byrne, G., Fragaszy, D. M., Visalberghi, E., Welker, C., \& Lussier, I. (2004). Twinning in tufted capuchins (Cebus apella): rate, survivorship, and weight gain. Folia primatologica, 75(1), 14-18.

17. Geissmann, T. (1990). Twinning frequency in catarrhine primates. Human Evolution, 5(4), 387396.

18. Chapman, C., \& Chapman, L. J. (1986). Behavioural development of howling monkey twins (Alouatta palliata) in Santa Rosa National Park, Costa Rica. Primates, 27(3), 377-381.

19. Bennett, E. L. (1982). The traumas of twins: Twinning and infant development in a wild arboreal colobine. Int. J. Primatol, 3, 260.

20. Bennett, E. L. (1988). The occurrence of twins and accompanying behavioural changes in the banded langur, Presbytis melalophos. Primates, 29(4), 557563.

21. Goodall, J. (1986). The chimpanzees ofGombe: Patterns of behaviour. Cambridge: Belknap The American Technological Challenge.
22. Hartman, C. G. (1943). Birth of a two-headed monster in the rhesus monkey. Science, 98(2551), 449-449.

23. Breitinger, E. (1951). Schimpansenzwillinge. Die Mehrfrüchtigkeit bei den Primaten. Die Umschau in Wissenschaft und Technik, 51(563.565).

24. Rajpurohit, L. S. (1987). Male social organization in Hanuman langurs (Presbytis entellus). PhD thesis, University of Jodhpur.

25. Rajpurohit, L. S., Srivastava, A., \& Mohnot, S. M. (1994). Birth dynamics in Hanuman langurs, Presbytis entellus of Jodhpur, India. Journal of Biosciences, 19(3), 315-324.

26. Devilal. (2009). Study of the Differential Population Growth in Natural and Artificial fed Groups of Hanuman langur (Semnopithecus entellus entellus). Ph.D. thesis. J.N.V. University, Jodhpur.

27. Mohnot, S. M. (1971). Some aspects of social changes and infant-killing in the Hanuman langur, Presbytis entellus (Primates: Cercopithecidae), in western India. Mammalia, 35(2), 175-198.

28. Srivastava, A. (1989). Feeding ecology and behaviour of Hanuman langur, Presbytis entellus. PhD Thesis.

29. Winkler, P. (1981). Zur Öko-Ethologie freilebender Hanuman-Languren (Presbytis entellus entellus Dufresne, 1797) in Jodhpur (Rajasthan), Indien (Doctoral dissertation, Uitgever niet vastgesteld).

30. Nakamichi, M. (1983). Development of infant twin Japanese monkeys (Macaca fuscata) in a freeranging group. Primates, 24(4), 576-583.

31. Taylor, T. D., \& Feistner, A. T. (1996). Infant rearing in captive Hapalemur griseus alaotrensis: singleton versus twins. Folia Primatologica, 67(1), 44-51.

32. Ellsworth, J. A., \& Andersen, C. (1997). Adoption by captive parturient rhesus macaques: Biological vs. adopted infants and the cost of being a "twin" and rearing "twins". American Journal of Primatology, 43(3), 259-264.

33. Ogawa, H. (1998). Adoption and social interactions between a mother and 'twin'offspring in Macasa fuscata. Folia Primatologica, 69(2), 100-105.

34. Ross, C. (2001). Park or ride? Evolution of infant carrying in primates. International Journal of Primatology, 22(5), 749-771.

35. Sharma, G. (2007). Paternal care in Hanuman langur, Semnopithecus entellus entellus, around Jodhpur (India) (Doctoral dissertation, $\mathrm{PhD}$ thesis, Jai Narain Vyas University, Jodhpur).

36. Sinha, A., Mukhopadhyay, K., Datta-Roy, A., \& Ram, S. (2005). Ecology proposes, behaviour disposes: Ecological variability in social organization and male behavioural strategies among wild bonnet macaques. Current Science, 1166-1179.

37. Ingmanson, E. J. (1996). Tool-using behavior in wild Pan paniscus: Social and ecological 
considerations. Reaching into thought: The minds of the great apes, 190-210.

38. Hsu, M. J., Jin-Fu, L., \& Agoramoorthy, G. (2000). Occurrence of twins in wild Formosan macaques, Macaca cyclopis, at Mt. Longevity, Taiwan. Folia Primatologica, 71(3), 154.

39. Sugiyama, Y., Kurita, H., Matsui, T., \& Shimomura, T. (2011). Twinning frequency of Japanese macaques (Macaca fuscata) at Takasakiyama. Primates, 52(1), 19-23.

40. Hsu, M. J., Moore, J., Lin, J. F., \& Agoramoorthy, G. (2000). High incidence of supernumerary nipples and twins in Formosan macaques (Macaca cyclopis) at Mt. Longevity, Taiwan. American Journal of Primatology: Official Journal of the American Society of Primatologists, 52(4), 199205.
41. Wu, H. Y. (1993). Seasonal variation of the activity and range use patterns of a wild troop of Formosan macaque in Kenting, Taiwan. Bull. Inst. Zool., 32, 242-252.

42. Wu, H. Y., \& Lin, Y. S. (1992). Life history variables of wild troops of Formosan macaques (Macaca cyclopis) in Kenting, Taiwan. Primates, 33(1), 85-97.

43. Pissinatti, A., Coimbra-Filho, A.F., Rylands, A.B., Nogueira, Rubiao., E.C. (1999). A twin birth in Cebus xanthosternos. Neotrop Primates, 7:21-24

44. Sierra-Marques, J. C., \& udia Calegaro-Marques, C. (1994). Activity budget and diet of Alouatta caraya: an age-sex analysis. Folia Primate, 63, 216-220.

45. Strier, K. B. (1991). Demography and conservation of an endangered primate, Brachyteles arachnoids. Conservation Biology, 5(2), 214-218. 